\title{
WORKING CAPITAL MANAGEMENT AND PROFITABILITY: A CASE OF ALBA COUNTY COMPANIES
}

\author{
Adina Elena Dănulețiu ${ }^{1}$
}

\begin{abstract}
The purpose of this study is to analyze the efficiency of working capital management of companies from Alba County. The relation between the efficiency of the working capital management and profitability is examined using Pearson correlation analyses and using a sample of 20 annual financial statements of companies covering period 2004-2008. The conclusion to our study is that there is a weak negative liniar correlation between working capital management indicators and profitability rates.
\end{abstract}

Keywords: working capital, profitability, Days Sales Outstanding, Days Inventory Outstanding, Days Payable Outstanding, Days Working Capital

JEL codes: G11, G30, G31

\section{Introduction}

The management of operating cycle is the most important section of the company's financial management. The objective of operating cycle's management is that of any capital investment: the most efficient allocation of capital in terms of risk decrease. The amortization of risk-profitability relation is mostly achieved within the balance between the need of circulating assets and sources mobilized for its funding.

To meet the need for profitability, the management of circulating assets aims at achieving the operating cycle with a minimum level of circulating assets, and the management of circulating liabilities aims at the lowest cost of procuring the necessary capital.

In order to meet the need for risk decrease, the management of circulating assets aims at eliminating the stock rupture, the lack of liquidities; a concern accompanied by higher operating costs and reduced profitability.

With respect to circulating liabilities, the financing sources constant, the financial autonomy of the operating cycle, preoccupations accompanied by increases in the cost of purchasing the necessary capital, are explored. Given these requirements to specifically optimize the riskprofitability relation, the management of the operating cycle consists of two complementary fields of activity:

- determining the required circulating assets (stocks, debts and liquidities);

- determining how to finance the required circulating assets (working capital, operating liabilities: suppliers, creditors etc.; banking competitions etc.).

The main feature of circulating assets is their high liquidity and hence the possibility of operational covering the debts from returns, of making investments and keeping a liquid reserve in the account and in the safe. There is a report specific for each company between sales (turnover) and the assets necessary to achieve them.

Starting from the ratio of sales (turnover) and the assets necessary to achieve them, but also from the analysis of working capital indexes, necessary working capital and net treasury, one can identify three politics of management operating cycle with different effects on profitability and risk:

1. Offensive/aggressive/attack policy (WC $<\mathrm{WCN}$ )

2. Defensive/ protective/prudential policy $(\mathrm{WC}>\mathrm{WCN})$

3. Balanced/ optimal policy $(\mathrm{WC}=\mathrm{WCN})$

\footnotetext{
1 “1 Decembrie 1918” University Alba Iulia, e-mail: adina.danuletiu@gmail.com
} 
Offensive policy is promoted by those managers who want to achieve a high turnover with minimum stocks implied. In this case, permanent capital absorbed in these physical or financial assets generates a working capital inferior to circulating assets during the year and for covering the deficit of working capital the company always calls on treasury credits. The strategy of funding the required working capital based on short-term bank loans involves some inconvenience. Thus, resorting to short-term loans over the medium and long term can lead to cost savings, but triggers the risk of insolvency in the case of resources' insufficiency and the need to call on other short term loans for financing current activity, showing a certain risk concerning the credit terms (higher interest rates, inability to renew loans, etc.). Under these circumstances, funding required working capital through short-term loans, better adapted to company's needs, may be more risky, the arbitrage between long-term and short-term actually relying on the anticipation of interest rate changes.

For these reasons, this policy can be judged as being a risky decision because the company depends on the bank's decisions concerning loans and interest. However, if the profitability is higher than the interest, this policy of the working capital is acceptable because it appears the positive effect of obligation.

Protective defensive policy is practiced by conservative leaders who aim to achieve a high turnover with high stocks and liquidities. For any increase in turnover, managers are concerned about the adequate increase of stocks that ensure the continuity of exploiting activity (current and safety stocks). Financing the financial necessary of the exploitation is carried out especially from permanent resources (working capital) ensuring the company's solvency, but in the same time assuming a higher cost of resources in relation to that of short-term bank loans, but also a coverage of loans' renewal risk and of interest increase rate; in other words, although the policy is costly and less profitable, it is more conservative.

Balanced policy has a neutral effect, because it is based on the principle of harmonization between the duration of temporal immobilization of circulating assets and the exigibility of liabilities meant to cover the financing needs in terms of minimizing financing costs and the risks the company is facing. "According to this policy, the increase of the activity is done with a current stock adequate to the turnover increase; in turn, safety stock is determined at optimal level, i.e. at the level where there is equality between the costs due to the lack of stock (out of stock) and excessive costs (over the strict requirements of the operation)." (Onofrei M, 2006, p.55)

Balanced policy is recommended because it keeps working capital at the average level of circulating assets fluctuations, this being the minimum required level of the working capital. If this strategy is used, during the peak of activity, the company calls on short-term loans, and when there is a gap in activity appears an excess of liquidities in the working capital that can be used for various short-term investments (Toma M., 1994, p.204). This policy is considered an equilibrium policy providing the best development of profitability and liquidity financial objectives: the diminishing of "lazy"(Stancu I., 1996, p. 326.) reserves will increase profitability and reducing the short-term loan applications will increase the ability to pay, respectively the company's financial autonomy. "Lazy" reserves are determined by the progressive growth of the net treasury, also determined by the progressive growth of the working capital, reserves which, in the absence of a profitable investment, have a high opportunity cost.

Balanced policy contributes to achieving the optimal working capital that maintains the company's financial balance at the lowest cost of procuring capitals. Thus, an efficient financial management, the result of expenditure savings achieved at the enterprise level is tested.

\section{Literature Review}

Many previous researches have indicated the relations between working capital management and profitability of a company in different environments. 
Shin and Soenen (1998) used a sample of 58,985 firm's years covering the period 19751994 in order to investigate the relation between net-trade cycle that was used to measure the efficiency of working capital management and corporate profitability. In all cases, they found a strong negative relation between the length of the firm's net-trade cycle and its profitability.

Deloof (2003) investigated the relation between working capital management and corporate profitability for a sample of 1,009 large Belgian non-financial firms for the period 1992-1996. The result from analysis showed that there was a negative gap between profitability that was measured by gross operating income and cash conversion cycle as well number of day's accounts receivable and inventories. He suggested that managers can increase corporate profitability by reducing the number of day's accounts receivable and inventories. Less profitable firms waited longer to pay their bills.

Lazaridis and Tryfonidis (2006) have investigated the relation between working capital management and corporate profitability of listed company in the Athens Stock Exchange. A sample of 131 listed companies for period of 2001-2004 was used to examine this relationship. The result from regression analysis indicated that there was a statistical significance between profitability, measured through gross operating profit, and the cash conversion cycle. From those results, they claimed that the managers could create value for shareholders by handling correctly the cash conversion cycle and keeping each different component to an optimum level.

Raheman and Nasr (2007) have selected a sample of 94 Pakistani firms listed on Karachi Stock Exchange for a period of 6 years from 1999-2004 to study the effect of different variables of working capital management on the net operating profitability. From result of study, they showed that there was a negative relations between variables of working capital management including the average collection period, inventory turnover in days, average collection period, cash conversion cycle and profitability. Besides, they also indicated that size of the firm, measured by natural logarithm of sales, and profitability had a positive relationship.

Garcia-Teruel and Martinez-Solano (2007) studied the effects of working capital management on the profitability of a sample of 8.872 small and medium-sized enterprises (SMEs) from Spain covering the period 1996 - 2002. They found that managers can create value by reducing their inventories and the number of days for which their accounts are outstanding. Moreover, shortening the cash conversion cycle also improves the firm's profitability.

Chakraborty (2008) evaluated the relationship between working capital and profitability of Indian pharmaceutical companies. He pointed out that there were two distinct schools of thought on this issue: according to one school of thought, working capital is not a factor of improving profitability and there may be a negative relationship between them, while according to the other school of thought, investment in working capital plays a vital role to improve corporate profitability, and unless there is a minimum level of investment of working capital, output and sales cannot be maintained - in fact, the inadequacy of working capital would keep fixed asset inoperative.

Singh and Pandey (2008) had an attempt to study the working capital components and the impact of working capital management on profitability of Hindalco Industries Limited for period from 1990 to 2007. Results of the study showed that current ratio, liquid ratio, receivables turnover ratio and working capital to total assets ratio had statistically significant impact on the profitability of Hindalco Industries Limited.

Finally, Afza and Nazir (2009) made an attempt in order to investigate the traditional relations between working capital management policies and a firm's profitability for a sample of 204 non-financial firms listed on Karachi Stock Exchange (KSE) for the period 1998-2005.The study found significant different among their working capital requirements and financing policies across different industries. Moreover, regression result found a negative relationship between the profitability of firms and degree of aggressiveness of working capital investment and financing 
policies. They suggested that managers could crease value if they adopt a conservative approach towards working capital investment and working capital financing policies.

The Amarjit Gill, Nahum Biger, Neil Mathur (2010) paper seeks to extend Lazaridis and Tryfonidis's findings regarding the relation between working capital management and profitability. A sample of 88 American firms listed on New York Stock Exchange for a period of 3 years from 2005 to 2007 was selected. They found statistically significant relation between the cash conversion cycle and profitability, measured through gross operating profit. It follows that managers can create profits for their companies by handling correctly the cash conversion cycle and by keeping accounts receivables at an optimal level.

\section{Methodology}

\section{Data collection}

In this paper, we used data collected from the financial statements of large companies from Alba County, financial statements filed by the economic agents at Public Finance Administration during 2004-2008. In the years 2005, 2006 and 2007 in the category of large companies there were 40 companies and in 2008, 46 companies. In order to compare the data on years, we have eliminated the companies that did not fall within large companies' category throughout the analyzed period and those companies with very large losses, and thus we came to a sample of 20 companies.

The assets' structure of the considered companies consists in 50\% capital and 50\% circulating assets.

\section{Variables}

In order to understand the relation that exists between the management of the operating cycle and profitability we have calculated the following indicators for the companies in the sample:

Net Working Capital (NWC), the financial security margin that allows the company to cope without difficulty with various short-term risks, being the expression of long term financial balance and its contribution to the achievement of short-term financial balance.

$$
\mathrm{NWC}=\mathrm{PC}-\mathrm{NFA} .
$$

Where: PC -permanent capital, NFA - net fixed assets

Working Capital Necessary (WCN) is the expression of achieving short-term balance, respectively the balance between the necessary and resources of circulating (current) capitals.

$\mathrm{WCN}=($ Current Assets - Short-term financial investments - Safe and bank accounts $)-$ (Current Debts - Amounts owed to credit institutions)

Net Treasury (NT) plays a fundamental role in a company, characterizing the amount of funds available at some point. Through it, it is realistically mirrored the short-term financial balance of companies by comparing the working capital to the working capital necessary.

$$
\mathrm{NT}=\mathrm{NWC}-\mathrm{WCN}
$$

Besides financial balance indicators, there were also determined the indicators of working capital management:

Days Sales Outstanding $(\mathrm{DSO})=$ Receivables/ $($ Sales/365)

Days Inventory Outstanding $(\mathrm{DIO})=$ Inventories/ $($ Sales/365)

Days Payable Outstanding $(\mathrm{DPO})=$ Payables/ $($ Sales/365)

Days Working Capital $($ DWC $)=$ DSO + DIO - DPO 
The profitability indicators used in this paper are:

Return on equity $(\mathrm{ROE})=$ Net income/Equity

Return on Assets $($ ROA $)=$ Net Income $/$ Total Assets

Return on Sales $(\mathrm{RS})=$ Net Income/Sales

Table no 1

Descriptive statistics of 20 non-financial companies during 2004-2008

\begin{tabular}{|c|c|c|c|c|c|}
\hline Indicator & & 2005 & 2006 & 2007 & 2008 \\
\hline \multirow{5}{*}{$\begin{array}{c}\text { Commercial } \\
\text { Profitability } \\
\text { (\%) }\end{array}$} & $\min$ & $0,05 \%$ & $0,06 \%$ & $0,05 \%$ & $0,03 \%$ \\
\hline & $\max$ & $25,21 \%$ & $29,67 \%$ & $16,59 \%$ & $10,44 \%$ \\
\hline & median & $1,72 \%$ & $2,95 \%$ & $3,70 \%$ & $1,59 \%$ \\
\hline & mean & $5,28 \%$ & $6,00 \%$ & $4,74 \%$ & $2,52 \%$ \\
\hline & st. dev & $7,01 \%$ & $7,38 \%$ & $4,53 \%$ & $2,88 \%$ \\
\hline \multirow{5}{*}{$\begin{array}{l}\text { Assets' } \\
\text { Profitability } \\
(\%)\end{array}$} & $\min$ & $-1,01 \%$ & $0,09 \%$ & $0,03 \%$ & $0,00 \%$ \\
\hline & $\max$ & $23,31 \%$ & $17,97 \%$ & $16,65 \%$ & $11,94 \%$ \\
\hline & median & $2,67 \%$ & $4,06 \%$ & $5,32 \%$ & $2,62 \%$ \\
\hline & mean & $5,63 \%$ & $6,34 \%$ & $5,80 \%$ & $3,87 \%$ \\
\hline & st. dev & $7,03 \%$ & $5,94 \%$ & $5,21 \%$ & $4,03 \%$ \\
\hline \multirow{5}{*}{$\begin{array}{l}\text { Financial } \\
\text { Profitability } \\
(\%)\end{array}$} & $\min$ & $0,15 \%$ & $0,13 \%$ & $0,05 \%$ & $0,02 \%$ \\
\hline & $\max$ & $81,63 \%$ & $92,16 \%$ & $36,63 \%$ & $23,22 \%$ \\
\hline & median & $10,24 \%$ & $14,18 \%$ & $14,76 \%$ & $5,13 \%$ \\
\hline & mean & $18,84 \%$ & $16,30 \%$ & $12,97 \%$ & $7,86 \%$ \\
\hline & st. dev & $22,91 \%$ & $20,38 \%$ & $10,50 \%$ & $7,52 \%$ \\
\hline \multirow{5}{*}{$\begin{array}{l}\text { Period for } \\
\text { Cashing } \\
\text { Receivables } \\
\text { (days) }\end{array}$} & $\min$ & 2,583 & 1,69 & 2,18 & 2,21 \\
\hline & $\max$ & 163,16 & 97,86 & 107,81 & 88,67 \\
\hline & median & 53,65 & 49,97 & 51,87 & 56,35 \\
\hline & mean & 60,92 & 50,23 & 54,73 & 51,16 \\
\hline & st. dev & 44,04 & 28,96 & 31,09 & 26,58 \\
\hline \multirow{5}{*}{$\begin{array}{l}\text { Storage } \\
\text { Period } \\
\text { (days) }\end{array}$} & $\min$ & 1,83 & 3,31 & 4,02 & 3,48 \\
\hline & $\max$ & 260,15 & 96,45 & 133,46 & 303,67 \\
\hline & median & 35,82 & 28,55 & 43,32 & 40,01 \\
\hline & mean & 56,66 & 41,18 & 52,54 & 61,41 \\
\hline & st. dev & 61,38 & 29,68 & 39,52 & 69,40 \\
\hline \multirow{5}{*}{$\begin{array}{l}\text { Period for } \\
\text { Paying } \\
\text { Debts } \\
\text { (days) }\end{array}$} & $\min$ & 0 & 15,67 & 18,23 & 14,65 \\
\hline & $\max$ & 411,29 & 144,67 & 143,10 & 146,15 \\
\hline & median & 42,60 & 32,71 & 39,41 & 36,93 \\
\hline & mean & 67,21 & 48,05 & 50,74 & 48,58 \\
\hline & st. dev & 87,96 & 36,80 & 36,57 & 35,26 \\
\hline \multirow{5}{*}{$\begin{array}{l}\text { Cash } \\
\text { Conversion } \\
\text { Cycle } \\
\text { (days) }\end{array}$} & $\min$ & $-1,39$ & $-15,22$ & 1,91 & $-7,57$ \\
\hline & $\max$ & 125,61 & 117,21 & 163,15 & 262,40 \\
\hline & median & 40,96 & 29,32 & 36,65 & 38,32 \\
\hline & mean & 50,36 & 43,36 & 56,53 & 63,99 \\
\hline & st. dev & 43,18 & 35,92 & 46,35 & 69,71 \\
\hline \multirow{5}{*}{$\begin{array}{l}\text { Working } \\
\text { Capital } \\
\text { (ron) }\end{array}$} & $\min$ & -5168494 & -8806774 & -8730765 & -17029721 \\
\hline & $\max$ & 8426158 & 12566204 & 13072690 & 12615798 \\
\hline & median & 518461 & 853322,5 & 1730425,5 & 1283267,5 \\
\hline & mean & 1549375 & 1981558,1 & 2928467,1 & 1845091,45 \\
\hline & st. dev & 3295280 & 4718624,5 & 4910965,4 & 7395649,358 \\
\hline
\end{tabular}




\begin{tabular}{|l|l|r|r|r|r|}
\hline \multirow{3}{*}{$\begin{array}{l}\text { Working } \\
\text { Capital }\end{array}$} & min & -998964 & -3153601 & -4085862 & -18238944 \\
\cline { 2 - 6 } $\begin{array}{l}\text { Necessary } \\
\text { (ron) }\end{array}$ & max & 10622547 & 10659099 & 12834518 & 14452068 \\
\cline { 2 - 6 } & median & 1040471 & 2352789 & 4498912 & 5222916 \\
\cline { 2 - 6 } & mean & 2278046 & 2862922,8 & 4781826,2 & 4382132,4 \\
\cline { 2 - 6 } & st. dev & 2989430 & 3590590,4 & 4421460,2 & 7485581,094 \\
\hline \multirow{4}{*}{\begin{tabular}{l} 
Net $\begin{array}{l}\text { Treasury } \\
\text { (ron) }\end{array}$ \\
\cline { 2 - 6 }
\end{tabular}} & Minim & -5453206 & -7202497 & -12281128 & -12367412 \\
\cline { 2 - 6 } & Maxim & 1589207 & 4951775 & 5426729 & 1532632 \\
\cline { 2 - 6 } & Median & 48325 & -1004123 & $-857561,5$ & -1550785 \\
\cline { 2 - 6 } & mean & -728671 & $-881364,7$ & -1853359 & $-2537040,95$ \\
\cline { 2 - 6 } & st. dev & 1648424 & 2833239,2 & 4358871,2 & 3989204,121 \\
\hline
\end{tabular}

From data in table 1 we can see that profitability rates of considered sample depreciated during 2006-2008.

In 2008, the cash conversion cycle is 63.9 days (the median of 38.32 days). Period for cashing receivables is 51 days (the median 56 days), while the companies pay their suppliers to 48 days (the median is at 36 days) and expect to sell their stocks during a period of 61 days (median is 40 days), which means that on average, the companies pay their debts faster than they cash receivables, so they are facing financial difficulties between these periods.

During the analyzed period we can see an increase of the deviation from the average cash conversion cycle, which indicates variations in the management of these indicators by companies.

Regarding the relation that exists between the average period of cashing receivables, the average period of storage and the average payment of suppliers, we can say that during 2005-2008 most companies were in the situation Ds + Dcr > Dc with the exception of two companies in 2006 and 2008 and a company in 2005. This situation shows that in order to ensure their solvency, these companies will resort to permanent resources or new short-term bank loans, a situation in which their profitability will be affected by some additional capital costs. Companies are in the position of providers of non-costly resources to their customers, transferring them a part of potential profits.

In 2008 only two companies were in the favorable situation Ds + Dcr < Ddc, in which case these companies accumulate additional liquidities by exploiting for themselves the attracted resources, particularly from suppliers, eroding their liquidity and implicitly affecting, through the aggravation of this situation, their profit. The profit translates into extra liquidities and, thus into non-costly increase of own capitals as a result of an efficient trade policy.

Regarding the relation between financial balance indicators: WC, WCN, NT, we carry forth a table that shows the situation of the studied companies.

From data in table 2 we can see that two of the 20 companies are in balance both on long and short term. These companies are the most stable from a financial point of view, being characterized by the existence of a certain short term financial autonomy; the companies' financing being made from the permanent capitals and non-financial temporary sources, without resorting to loans; there is a positive gap between the liquidation of stocks and claims and the exigibility of operating debts in terms of speeding the rotation of circulating assets, urging chasing and relaxing the payments; basically there is no necessary to be financed which leads to a positive net treasury. 
Table no 2.

The situation of sample companies in terms of the relation between financial balance indicators during 2004-2008

\begin{tabular}{|c|c|c|c|c|c|c|c|}
\hline Case & \multicolumn{3}{|c|}{ Balance Indicators } & 2005 & 2006 & 2007 & 2008 \\
\hline 1 & NWC + & WCN - & NT + & 2 & 3 & 2 & 2 \\
\hline 2 & NWC + & WCN+ & NT + & 7 & 6 & 5 & 4 \\
\hline 3 & NWC + & WCN+ & NT - & 5 & 7 & 11 & 10 \\
\hline 4 & NWC - & WCN- & NT + & 4 & 0 & 1 & 1 \\
\hline 5 & NWC - & WCN- & NT - & 0 & 1 & 0 & 2 \\
\hline 6 & NWC - & WCN+ & NT - & 4 & 3 & 1 & 1 \\
\hline
\end{tabular}

During 2005-2008 the number of companies in situation 2 decreased and the number of in situation 3 increased.

The companies in the second situation are characterized by the fact that within their work, investments concerning the increase of financing necessary of operating cycle occur, short-term debts not being enough to meet the current activity, so they are in short-term imbalance. The shortterm imbalance may suggest two things:

- a normal situation, where the need for additional financing of current activity is due to changes in manufacturing technology or the extension of the operating cycle and, on this basis the growth of stocks or circulating assets waiting to be offset is justified. Also, the growth of the volume of operating activity due to some offer adjustments towards the manifestation of a favourable request on the market of specific products may generate additional short-term need for financing the circulating assets, without being the expression of an alarming financial imbalance.

- a negative situation, if there is a slowing in stocks' rotation (the decrease of products' demand, the incorrect determination of stocks' level, the reorientation of production, technological reorganization etc.); a slowing of cashing and, generally, the unfavourable management of debtobligations ratio which means that the company does not attract enough non-financial sources to cover the current needs.

On long term, the permanent capital covers the immobilized assets, these companies disposing of safety margin which ensures its daily operation so these are in long-run equilibrium, and by the fact that the working capital is greater than the working capital necessary the treasury of these companies is positive.

Although in long-term equilibrium, companies in the third situation are facing an unfavorable gap between stocks and claims' liquidation and the exigibility of operating debts in terms of slowing the revenue and accelerating the payments, resulting in a negative treasury. While the situation illustrates a certain limitation of the company's financial independence, it should not be interpreted as a state of insolvency. Companies will need to take steps to recover debts, to accelerate the speed of stocks' rotation and eventually to re-launch the term of temporary resources, which will lead to a decrease of working capital necessary and hence the treasury deficit. If the normal course of operating cycle allows the justification of resorting to the financing of circulating assets a proportion based on short-term bank loans, the company's financial creditworthiness does not appear to be compromised by negative cash. This is confirmed by the reality, with the help of financial statistics, showing that in most economic sectors companies have negative treasury situations, and these circumstances do not affect their financial health.

By exception, negative net working capital can be recorded in those companies which through their activity profile liquidate and renew stocks very quickly, such as wholesale and retail trade companies or those working on the basis of advances and guarantees such as the companies 
supplying electricity and gas, companies which on the other hand, benefit of a range of facilities regarding the payments to their suppliers (they have no access to supplier credit).

The number of companies in the fourth situation has been declining over time, which is a positive aspect. These companies are facing the acceleration of stocks and operating claims' rotation leading to the reduction and even the lack of working capital necessary, these being in short-term balance. On long term however, companies are unbalanced failing to cover the capital assets from permanent capital so they do not have a working capital, being forced to resort to longterm loans. Positive net treasury results from speeding the cashing and easing the payments.

There was one company in the fifth situation in 2006 and two in 2008. For these companies, the negative net treasury results from slowing the cashing, accelerating the payments and from supporting the investment policy. Long-term financial imbalance can have an economic justification found in the intention to increase the technical-productive base. A certain amount of ongoing activity that can not be covered by permanent sources is partially financed based on temporary sources (a situation which, however, is contrary to the general principles of the financial balance) and the additional need to finance the immobilized assets remained uncovered is in the treasury which becomes negative.

The number of companies in the sixth situation fell from 4 in 2005 to 1 in 2008 . These companies are both in long-term imbalance because they do not cover the capital assets from permanent capitals and in short-term imbalance because the current debts are not enough to finance the current assets, being a negative gap between the liquidity of stocks and receivables and exigibility of operating debts, in terms of slowing the cashing and accelerate the payments which leads to a negative net treasury.

From the 20 analyzed companies, only nine have applied an offensive policy of operating cycle management in 2005 and 11 companies have adopted a defensive policy, the situation has changed in 2008, the number of companies that have implemented an offensive policy increased to 13 and the number of companies that have applied a defensive policy fell to 7 .

Next, we have calculated Pearson's correlation coefficient between result indicators, financial balance indicators and financial management indicators of the operating cycle.

Pearson's correlation coefficient between two variables is defined as the covariance of the two variables divided by the product of their standard deviations:

$$
r=\frac{\sum_{i=1}^{n}\left(X_{i}-\bar{X}\right)\left(Y_{i}-\bar{Y}\right)}{\sqrt{\sum_{i=1}^{n}\left(X_{i}-\bar{X}\right)^{2}} \sqrt{\sum_{i=1}^{n}\left(Y_{i}-\bar{Y}\right)^{2}}} .
$$

The correlation coefficient ranges from -1 to 1 . A value of 1 implies that a linear equation describes the relationship between $X$ and $Y$ perfectly, with all data points lying on a line for which $Y$ increases as $X$ increases. A value of -1 implies that all data points lie on a line for which $Y$ decreases as $X$ increases. A value of 0 implies that there is no linear correlation between the variables.

The results of Pearson's correlation coefficient are reflected in the table no 3. 
Table no 3.

Pearson's correlation coefficients in 20 non-financial companies, 2004-2008

\begin{tabular}{|c|c|c|c|c|c|c|c|c|c|}
\hline 2008 & $\mathrm{ROA}$ & $\mathrm{ROE}$ & DSO & DIO & DPO & DWC & NWC & $\mathrm{WCN}$ & NT \\
\hline $\mathrm{RS}$ & 0,8445 & 0,6907 & $-0,1340$ & 0,0903 & $-0,2881$ & 0,1846 & 0,3259 & 0,2280 & 0,1764 \\
\hline ROA & & 0,8709 & $-0,1868$ & $-0,0828$ & $-0,3353$ & 0,0159 & 0,3146 & 0,1995 & 0,2088 \\
\hline ROE & & & $-0,1019$ & $-0,1721$ & $-0,2710$ & $-0,0732$ & 0,2681 & 0,2459 & 0,0357 \\
\hline DSO & & & & 0,164 & 0,545 & 0,269 & $-0,105$ & 0,084 & $-0,352$ \\
\hline DIO & & & & & 0,304 & 0,904 & 0,113 & 0,178 & $-0,125$ \\
\hline DPO & & & & & & 0,005 & $-0,591$ & $-0,403$ & $-0,340$ \\
\hline DWC & & & & & & & 0,371 & 0,412 & $-0,086$ \\
\hline NWC & & & & & & & & 0,226 & $-0,268$ \\
\hline $\mathrm{WCN}$ & & & & & & & & & $-0,268$ \\
\hline 2007 & $\mathrm{ROA}$ & ROE & DSO & DIO & DPO & DWC & NWC & $\mathrm{WCN}$ & NT \\
\hline $\mathrm{RS}$ & 0,8770 & 0,6042 & $-0,0075$ & $-0,1690$ & $-0,0897$ & $-0,0784$ & 0,3957 & $-0,0030$ & 0,4488 \\
\hline ROA & & 0,6797 & 0,0238 & $-0,2211$ & $-0,0595$ & $-0,1256$ & 0,2379 & $-0,1695$ & 0,4399 \\
\hline ROE & & & $-0,0094$ & $-0,4391$ & $-0,0444$ & $-0,3458$ & 0,1104 & $-0,0072$ & 0,1317 \\
\hline DSO & & & & $-0,121$ & 0,497 & $-0,037$ & 0,195 & 0,286 & $-0,070$ \\
\hline DIO & & & & & 0,338 & 0,781 & $-0,019$ & 0,214 & $-0,239$ \\
\hline DPO & & & & & & $-0,071$ & $-0,358$ & $-0,123$ & $-0,280$ \\
\hline DWC & & & & & & & 0,349 & 0,473 & $-0,087$ \\
\hline WC & & & & & & & & 0,568 & 0,550 \\
\hline NWC & & & & & & & & & $-0,374$ \\
\hline 2006 & $\mathrm{ROA}$ & $\mathrm{ROE}$ & DSO & DIO & $\mathrm{DPO}$ & DWC & NWC & WCN & NT \\
\hline $\mathrm{RS}$ & 0,4449 & 0,863 & $-0,0551$ & $-0,0522$ & $-0,1898$ & 0,1069 & 0,4572 & 0,3320 & 0,3408 \\
\hline ROA & & 0,2297 & $-0,1326$ & $-0,2120$ & $-0,2536$ & $-0,0223$ & 0,0742 & $-0,1507$ & 0,3145 \\
\hline $\mathrm{ROE}$ & & & $-0,1945$ & $-0,2280$ & $-0,2788$ & $-0,0596$ & 0,4485 & 0,3816 & 0,2633 \\
\hline DSO & & & & 0,019 & 0,263 & 0,350 & 0,246 & 0,323 & 0,001 \\
\hline DIP & & & & & 0,021 & 0,639 & 0,081 & 0,279 & $-0,220$ \\
\hline DPO & & & & & & $-0,206$ & $-0,461$ & $-0,339$ & $-0,338$ \\
\hline DWC & & & & & & & 0,561 & 0,699 & 0,048 \\
\hline $\mathrm{WCN}$ & & & & & & & & 0,801 & 0,651 \\
\hline NWC & & & & & & & & & 0,066 \\
\hline 2005 & ROA & $\mathrm{ROE}$ & DSO & DIO & DPO & DWC & NWC & $\mathrm{WCN}$ & NT \\
\hline $\mathrm{RS}$ & 0,4348 & 0,6539 & $-0,0397$ & $-0,1705$ & $-0,2530$ & 0,2326 & 0,1911 & 0,099 & 0,201 \\
\hline ROA & & 0,1789 & $-0,2710$ & $-0,3065$ & $-0,2385$ & $-0,2262$ & $-0,0822$ & $-0,201$ & 0,200 \\
\hline ROE & & & 0,1580 & 0,2915 & 0,2864 & $-0,0080$ & 0,0273 & $-0,006$ & 0,065 \\
\hline DSO & & & & $-0,143$ & 0,108 & 0,245 & 0,473 & 0,547 & $-0,046$ \\
\hline DIP & & & & & 0,748 & 0,309 & 0,003 & $-0,009$ & 0,023 \\
\hline DPO & & & & & & $-0,226$ & $-0,270$ & $-0,351$ & 0,096 \\
\hline DWC & & & & & & & 0,579 & 0,617 & 0,040 \\
\hline $\mathrm{WC}$ & & & & & & & & 0,867 & 0,427 \\
\hline NWC & & & & & & & & & $-0,081$ \\
\hline
\end{tabular}

Throughout the analyzed period we can see an inverse relation between the indicators of working capital management (duration of cashing receivables, duration of paying the debts and the 
duration of storage) and profitability indicators (commercial profitability, assets' profitability and financial profitability).

There is a strong direct connection between the cash conversion cycle and the stocks' rotation speed by turnover in 2008 , a connection that has strengthened year to year, being less intense in 2005.

Although during 2005-2007 between the net result and the operating result exists a strong connection, this has become weak in 2008.

Throughout the period there is an inverse relation between the duration of storage and the profitability indicators, between net result and operating result. This connection may be caused by sales' dropping, which is reflected in profit dropping due to increasing the stocks.

Throughout the period there is an inverse relation between WC and NWC and the duration of paying the suppliers.

If during 2005-2007 between WCN, respectively NWC and the duration of cashing receivables was a weak direct connection, in 2008 the connection between these indicators became indirect.

Pearson's correlation limits do not allow us to identify the causes for the consequences.

\section{Conclusion}

From the study we can say that two of the twenty companies are in balance, both on long and short term. In the last year, half of the sampled companies had a negative gap between stocks and claims' liquidation and the exigibility of operating debts in terms of slowing the cashing and accelerating the payments, resulting in negative treasury.

From the 20 analyzed companies, only nine have applied an offensive policy of operating cycle management in 2005 and 11 companies have adopted a defensive policy, the situation has changed in 2008, the number of companies that have implemented an offensive policy increased to 13 and the number of companies that have applied a defensive policy fell to 7 .

This situation results also from the negative weak relation between working capital management indicators and profitability rates. The weak resulted connection can be explained by the fact that the sampled companies belong to different fields of activity.

\section{References}

1 Afza, T., Nazir, M., 2009. Impact of aggressive working capital management policy on firms' profitability, The IUP Journal of Applied Finance, 15(8), 20-30

2. Chakraborty, K., 2008. Working Capital and Profitability: An Empirical Analysis of Their elationship with Reference to Selected Companies in the Indian Pharmaceutical Industry, The Icfai Journal of Management Research

3. Deloof, M., 2003. Does working capital management affects profitability of Belgian Firms?, Journal of Business Finance \& Accounting, 30(3-4), 573-588

4. Dănulețiu A. E., 2009. Analiza echilibrului financiar al firmei, Aeternitas Publishing House, Alba Iulia

5. Dănulețiu A.E., Dănulețiu D.C., 2008. Assessing Financial Equilibrium of The Romanian Companies Traded At Bucharest Stock Exchange, Annals of University of Craiova Economic Sciences Series, 1(36), pages 272-277

6. Dănulețiu A.E., Dănulețiu D.C., 2008. The Financial Equilibrium And Competitiveness Within Agricultural Holdings, Annales Universitatis Apulensis series Oeconomica, 10(1), pp. $402-410$

7. Garcia-Teruel, P.J., Martinez-Solano, P., 2007. Effects of working capital management on SME profitability, International Journal of Managerial Finance, Vol.3, Issue 
8. Gill A., Biger N., Mathur N., 2010. The Relation Between Working Capital Management And Profitability: Evidence From The United States, Business and Economics Journal, Volume 2010: BEJ-10.

9. Lazaridis, I., Tryfonidis, D., 2006. Relationship between working capital management and profitability of companies listed in the Athens Stock Exchange, Journal of Financial Management and Analysis, 19(1), 26-35

10. Onofrei M., 2006. Management financiar, CH. Beck Publishing House, Bucharest, p.55

11. Raheman, A., Nass, M 2007, Working capital management and profitability-case of Pakistani firms, International Rewiew of Business Research Papers 3 (1), 279-300

12. Shin, H., H., Soenen, L. 1998. Efficiency of working capital management in the profitability of Hindalco Industries Limited, Icfai University Journal of Financial Economics, 6(4), 62-72

13. Stancu, I. 1996. Finanțe, Economica Publishing House, Bucharest, pp. 326

14. Toma M., 1994. Finanțe şi gestiune financiară de întreprinderi, Economica Publishing House, Bucharest, pp.204 